\title{
An insight into online encyclopaedias for children and young adults
}

\author{
Cvijeta Kraus \\ The Miroslav Krleža Institute of Lexicography \\ Frankopanska 26, Zagreb, Croatia \\ cvijeta.kraus@lzmk.hr \\ Nataša Jermen \\ The Miroslav Krleža Institute of Lexicography \\ Frankopanska 26, Zagreb, Croatia \\ natasa.jermen@lzmk.hr \\ Zdenko Jecić \\ The Miroslav Krleža Institute of Lexicography \\ Frankopanska 26, Zagreb, Croatia \\ zdenko.jecic@lzmk.hr
}

\section{Summary}

Online encyclopaedias and encyclopaedic portals for children and young adults serve as useful tools for acquiring knowledge. This paper presents the results of the analysis of functionalities of three online encyclopaedias for children and young adults, Britannica Kids, Q-files and KidzSearch Encyclopedia in the digital environment. A set of basic criteria for the evaluation of usability of online encyclopaedias intended for young users were established. These criteria could serve as the basis for the definition of a concept for production of online encyclopaedic works for children and young adults.

Key words: children's encyclopaedia, young adult's encyclopaedia, encyclopaedia's evaluation criteria, educational website

\section{Introduction}

Children and young adults are strongly oriented towards information technologies. The primary sources of information in their world are often (although not exclusively) digital, which is quite different from any generation prior. ${ }^{1}$ Therefore, there is a need to ensure that they are furnished with the safe and trusted environments, as well as with the digital content which is trustworthy and suita-

\footnotetext{
${ }^{1}$ Flanagin Andrew J.; Metzger Miriam J. Digital Media and Youth: Unparalleled Opportunity and Unprecedented Responsibility. // MacArthur Foundation Series on Digital Media and Learning. Cambridge, MA: The MIT Press, 2008, p. 6
} 
ble to their needs. As encyclopaedias have always formed an important part of the infrastructure for learning in schools, ${ }^{2}$ online encyclopaedias and encyclopaedic portals could represent a very important component of educational e-infrastructure serving as the didactic tools for electronically supported learning and teaching. ${ }^{3}$ As such they should be considered as a specific type of educational websites - the sites created with the purpose of educating their users about a certain topic or the sites that are adapted for schools in accordance with curriculum subjects.

General encyclopaedias are intended for a wide range of users, tending to avoid explaining well-known, as well as overly professional terms. Consequently, it is considered that they are adapted for adult users who have the necessary average pre-knowledge for using encyclopaedias. Since this does not cover the needs of the very young audience, specialised encyclopaedic works for children and young adults are being published. One of the first encyclopaedic works for children was Orbis Pictus (Visible World in Pictures), which was published in Bratislava in 1658 by a Czech teacher Johann Amos Comenius. Encyclopaedias for children ${ }^{4}$ are mainly targeted at primary school children, from 6 or 7 to 12 or 14 years old. These encyclopaedias mostly contain a smaller number of review articles that elaborate a larger number of topics. The articles can be organised alphabetically or thematically. The writing style is simple, as well as the language, and the articles' structure is not strictly determined. Special attention is paid to the illustrations, that are usually more common compared to other encyclopaedias, as well as to the attractive graphic editing. These elements are supposed to attract the attention and interest of younger users. Encyclopaedias for young adults ${ }^{5}$ are targeted at users above 12 years old. They encompass a larger

\footnotetext{
${ }^{2}$ Sundin, Olof; Haider, Jutta. The networked life of professional encyclopaedias: Quantification, tradition, and trustworthiness. // First Monday, 8 (2013) 6.

${ }^{3}$ Croatian national educational strategy, for example, points out that e-learning and e-education provide access to updated and current multimedia and interactive teaching materials and enable the use of the repositories of didactic material, digital libraries, archives and museums. The development of educational e-content includes creation of open repositories of knowledge and didactic tools (for example digitised books and lexicons). Strategy of education, science and technology (in Croatian), Official Gazette 124/2014.

${ }^{4}$ Examples of traditional printed encyclopaedias for children: My First Britannica (Chicago: Encyclopædia Britannica, 2004; 13 volumes, 525 articles, 1288 pages, 800 illustrations; age group 6 to 10); Britannica student encyclopedia (Chicago: Encyclopædia Britannica, 2007; 16 volumes, 2250 articles, 2900 pages, 2700 illustrations; age group 7 to 12.); Der Kinder Brockhaus in drei Bänden (5th edition Mannheim: Bibliographisches Institut \& F. A. Brockhaus, 2006; 3 volumes, 1000 articles, 676 pages, 2000 illustrations; age group 7 to 12).

${ }^{5}$ Examples of traditional printed encyclopaedias for young adults: Compton's by Britannica (Chicago: Encyclopædia Britannica, 2008; 26 volumes, 37000 articles, 11000 pages, 23000 illustrations; age group 10 to 17); Der Jugend Brockhaus in drei Bänden (6th edition, Mannheim: Bibliographisches Institut \& F. A. Brockhaus, 2005; 3 volumes, 10000 articles, 1200 pages, 2000 il-
} 
C. Kraus, N. Jermen, Z. Jecić, An insight into online encyclopaedias for ...

number of articles that elaborate on narrower terms when compared to encyclopaedias for children. They are adapted for school and homework assignments, and often bring references for additional reading.

Information and communication technologies (ICT) have given rise to the specialised internet sources for younger audience, for example specialised search engines, fun sources, sources of knowledge etc. Online encyclopaedias for children and young adults are sources that cover many topics, and as such they represent comprehensive sources of knowledge. One of the first online encyclopaedias for children and young adults was The World Book Encyclopedia ${ }^{6}$ published on the internet in 1998. New encyclopaedic sources of knowledge have been continuously developed, for example Q-files, KidzSearch Encyclopedia, and especially Fact Monster, Encyclopedia Smithsonian, Encyclopedia.com, Britannica Kids. ${ }^{7}$

\section{Scope of research}

This paper aims to explore the functionalities of online encyclopaedic portals for children and young adults in the digital environment. Basic criteria for the evaluation of usability of online encyclopaedias intended for children and young adults will be elaborated. The assumption is that established criteria could serve as the basis for the definition of a concept for production of online encyclopaedias intended for young users. The research was limited to the websites that, despite of their unspecified format, could be considered encyclopaedias, since they have clearly articulated articles that contain a title (article's name) and textual explanation of the subject named in the article's title. This definition meant that the analysis embraced only a small amount of different online sources for children and young adults aimed at acquiring knowledge through fun or at helping to follow curriculum subjects.

\section{Analysis of online encyclopaedias for children and young adults}

Three online encyclopaedias for children and young adults were chosen for the analysis: Britannica Kids, Q-files and KidzSearch Encyclopedia.

\subsection{Encyclopædia Britannica for children and young adults - Britannica Kids}

Encyclopcedia Britannica ${ }^{8}$ was first published in 1768 in Edinburgh, Scotland. By its eleventh edition released in 1911, it was hailed as the greatest encyclope-

lustrations; age group 12 and above); Svijet oko nas, enciklopedija za djecu i omladinu (Zagreb: Školska knjiga, 1960; 2 volumes, 600 pages; age group 10 to 16).

${ }^{6}$ World Book Online, http://www.worldbookonline.com (3.6.2017).

${ }^{7}$ Rain, Ella. Childrens Online Encyclopedia, http://childrens-books.lovetoknow.com/Childrens Online_Encyclopedia (26.6.2017).

${ }^{8}$ Encyclopaedia Britannica, https://www.britannica.com (2.6.2017). 
dia in the world. ${ }^{9}$ In 1994 Encyclopaedia Britannica published its first CDROM and the online edition (Britannica online ${ }^{10}$ ), becoming the first printed encyclopaedia whose digital version appeared on the internet. Having a reputation of being the universally acknowledged outstanding reference work, it soon became the leading publisher of digital encyclopaedic editions, particularly after it stopped publishing printed editions in 2012. At present, the main Encyclopcedia Britannica's website (britannica.com) offers access to other specialised websites of the same publisher. One of those websites is the encyclopaedic portal for children and young adults Britannica Kids. ${ }^{11}$

The main goal of Britannica Kids is to provide easily accessible safe and trusted content to children and teenagers in order to support their homework needs based on a variety of curriculum subjects and standards. The content is gathered from the "great intellects across the globe - including leading educators, Pulitzer Prize winners and Nobel laureates" and edited by a skilled in-house editorial staff. $^{12}$

Targeted for children and young adults from kindergarten to high school and beyond, this website is divided into three reading levels that are adapted to a certain age-group and expected pre-knowledge: Britannica KIDS - up to grade 5 (up to 11 years old); Britannica STUDENTS - grade 6-8 (from 11 to 14 years old); Britannica SCHOLARS - grade 9 and up (above 15 years old). After registration the user selects the desired level (separate websites) on the homepage of the portal.

Certain functionalities are mutual for all three reading levels. The homepage of each of these websites contains a simple search engine, as well as a visually smaller more advanced search engine that provides a drop-down list of possible results. Presentation of search results is the same on all three websites: the list of articles that contain a searched topic, multimedia elements and links to additional sources. Upon opening a selected article the user can easily access the same article on the remaining two reading levels. Furthermore, it is possible to share the article via e-mail, to print, cite and translate it. Audio reproduction of the content is enabled.

\subsubsection{Britannica KIDS}

Britannica KIDS ${ }^{13}$ homepage contains interactive content (a quiz) that enables children to initiate their exploration. Besides searching with the search engine,

\footnotetext{
${ }^{9}$ Auchter, Dorothy. The evolution of the Encyclopaedia Britannica: from Macropaedia to Britannica Online // Reference Services Review, 27 (1999) 3, p. 291.

${ }^{10}$ At the time at: http://www.eb.com/eb.html

${ }^{11}$ Britannica Kids, http://kids.britannica.com/ (2.6.2017).

${ }^{12}$ Britannica Kids, http://kids.britannica.com/about (2.6.2017).

${ }^{13}$ Britannica Kids, Kids, http://kids.britannica.com/kids (2.6.2017).
} 
C. Kraus, N. Jermen, Z. Jecić, An insight into online encyclopaedias for ...

there is a possibility for browsing of certain sections (Articles, Images\&Video, Biographies, Animal Kingdom, World Atlas, Dictionary), that contain thematically or alphabetically organised content.

This encyclopaedic website contains very simple content, adapted for the youngest users. Articles are divided into chapters (the user can decide which chapter to open), accompanied with images and links to the related articles. As well, there is a section Did you know? that highlights out article's interesting facts.

\subsubsection{Britannica STUDENTS \& Britannica SCHOLARS}

The homepage of Britannica STUDENTS ${ }^{14}$ \& Britannica SCHOLARS $S^{15}$ brings a lot of additional content (presentation of current events, additional sections such as Can you guess? Did you know?), but the search engine is always visible on the page. Once search results have been displayed there is a possibility to carry out additional advanced search. As is the case for Britannica KIDS, browsing of main sections, that contain thematically or alphabetically organised content, is enabled. At these two levels, searching of sections' content is more advanced and enables different types of queries.

The content of these two reading levels differs with respect to comprehensiveness and the presentation of multimedia elements. Britannica STUDENTS offers a simpler content, adapted to younger users. Content at the Britannica SCHOLAR level is actually provided from Encyclopaedia Britannica (articles are signed by the contributors), although its presentation is more simplified. Articles at both reading levels are divided into chapters, which are listed in the left panel and are easy to navigate accompanied with multimedia elements and related resources (articles, primary sources and e-books, and websites).

\subsection{Q-files - The Great Illustrated Encyclopedia}

One of online encyclopedias designed especially for children is $Q$-files - The Great Illustrated Encyclopedia ${ }^{16}$ by Orpheus Books Limited, based in Oxford, England. Established in 1993, this publishing house is one of the world's leading producers of children's non-fiction and reference books. The site $Q$-files was launched in 2015. primarily for children aged 8 to 14-years-old. As of June 2017, Q-files is now a subscription service. ${ }^{17}$ The content of $Q$-files has been drawn from Orpheus's reference book archive and prepared by specialist children's writers and experienced editorial team, under the expert guidance of the

\footnotetext{
${ }^{14}$ Britannica Kids, Students, http://kids.britannica.com/students (2.6.2017).

${ }^{15}$ Britannica Kids, Scholars, http://kids.britannica.com/scholars (2.6.2017).

${ }^{16}$ Q-files - The Great Illustrated Encyclopedia, https://www.q-files.com/home/ (3.6.2017).

${ }^{17}$ ClassConnect, http://connect.learnpad.com/content/activity.cfm?id=286650 (8.6.2017).
} 
consultants who worked on the original titles. Users can therefore be assured of the highest standards of accuracy and reliability. ${ }^{18}$

The homepage of this website is visually designed for children and provides access only to the selected content. For the complete access to the content a user needs to register as a home (individual) user or as a school user. The homepage for individual users doesn't provide access to the search by topics and doesn't contain a simple search engine. The individual user can access these functionalities only after opening a selected article on the homepage. School users are equipped with more elaborated homepage that provides search by topics and simple search engine. Every article attaches active links to the similar content on the same site and a Q-facts section with main information about the article. $Q$-files encyclopedia contains a lot of multimedia elements (images, tables, timelines) and provides a print option. The site has a presence on the social networks.

\subsection{Wikipedia for children - KidzSearch Encyclopedia}

Wikipedia $^{19}$ is a web-based, multilingual and free-access encyclopedia developed in 2001. Based on anonymous collaborative editing, Wikipedia soon became the largest and the most popular encyclopaedia in the world. The Kidz Search Encyclopedia ${ }^{20}$ is based on Simple English Wikipedia, which is similar to regular Wikipedia, but written at a level much more appropriate for children. Editorial staff manually approve all the entries and may also add unique original articles themselves. It is important to point out that unauthorized staff cannot change the pages on KidzSearch site. ${ }^{21}$

As in Wikipedia, content of KidzSearch Encyclopedia is free and accessible without registration. The homepage provides a simple search engine and a list of topics to search, accompanied by a few representative articles. The list of topics is also present in the left panel, where each topic is linked to an article that explains it. Search by a search engine takes the user to another website kidzsearch.com, which provides the results from other sources besides Kidz Search encyclopedia (other web sites, images, videos, facts, news, games etc.). To access the KidzSearch encyclopedia content, it is necessary to select the section wiki at the website menu. Articles in KidzSearch encyclopedia are organized in the same way as in Wikipedia; they are divided into chapters, contain

\footnotetext{
${ }^{18}$ Q-files - The Great Illustrated Encyclopedia https://www.q-files.com/about-q-files/ (3.6.2017).

${ }^{19}$ Wikipedia: The Free Encyclopedia, Wikimedia Foundation Inc., http://www.wikipedia.org, (29. 7.2008).

${ }^{20}$ KidzSearch Encyclopedia, http://wiki.kidzsearch.com/wiki/Main_Page (3.6.2017).

${ }^{21}$ KidzSearch Encyclopedia, http://wiki.kidzsearch.com/wiki/KidzSearch_Encyclopedia:About (9.6.2017).
} 
C. Kraus, N. Jermen, Z. Jecić, An insight into online encyclopaedias for ...

images, links to other articles within encyclopaedia as well as to the external sources, references and an information box with main facts.

\subsection{Comparative analysis of the content organization and presentation}

The most important part of a website is its content that has to be engaging, relevant and appropriate to the audience. ${ }^{22}$ In the case of encyclopaedias, it is important to ensure that the information in the articles is structured and presented according to the encyclopaedic principles. ${ }^{23}$

We analysed content organisation and presentation of the encyclopaedic entries in Britannica Kids, Q-files and KidzSearch Encyclopedia. Assessing the content in terms of its reliability was beyond the scope of this research. Nevertheless, it is important to stress that every encyclopaedic website should provide accurate, up to date and appropriate information for its end-users.

Based on the comparative analysis of several encyclopaedic entries in each of the analysed encyclopaedias, we established that there are certain patterns in the way that content is organised and presented. We will show the main characteristics in content organisation and presentation in each of the analysed encyclopaedia using the example of the article Croatia:

- Britannica KIDS. ${ }^{24}$ Very simple content that doesn't contain a clear definition. The article is divided into 5 chapters, containing 4 images, an audio clip of the Croatian national anthem and a link to related articles.

- Britannica STUDENTS. ${ }^{25}$ More extensive content without a clear definition in the introduction. The left panel offers a list of chapters, a Quick Facts box that contains a compilation of the key information about the state and the links to other related resources. The article is divided into 5 chapters, containing 5 images and an audio clip of the Croatian national anthem.

- Britannica SCHOLARS. ${ }^{26}$ The most extensive content that contains a definition. It is divided into 8 chapters, with additional subchapters, containing 30 images, 2 video clips and an audio clip of the Croatian national anthem The list of chapters is placed in the left panel together with a detailed Quick Facts box and the links to other related resources. As previ-

\footnotetext{
${ }^{22}$ HHS Web Standards and Usability Guidelines, https://guidelines.usability.gov/guidelines/1 (5.6.2017).

${ }^{23}$ Jecić, Zdenko. Enciklopedički koncept u mrežnom okruženju. // Studia lexicographica, 7 (2013), 2 (13), p. 113

${ }^{24}$ Britannica Kids, Kids, http://kids.britannica.com/kids/article/Croatia/345673 (7.6.2017).

${ }^{25}$ Britannica Kids, Students, http://kids.britannica.com/students/article/Croatia/273859 (7.6.2017).

${ }^{26}$ Britannica Kids, Scholars, http://kids.britannica.com/scholars/article/Croatia/110562 (7.6.2017).
} 
ously mentioned, the article's content in Britannica SCHOLARS is the same as the one in britannica.com ${ }^{27}$.

- $Q$-files ${ }^{28}$. Simple content with a short definition. The article contains a small information box with main facts about the state. Content is divided into 3 chapters and contains 10 images.

- KidzSearch ${ }^{29}$. Simple content with a short definition The information box is organised in the same way as in regular Wikipedia. Content is divided into 3 chapters and contains 2 images.

\section{Evaluation of online encyclopaedias for children and young adults}

At a time of numerous websites for children and young adults that offer encyclopaedic content, learning through fun or help with learning, parents, teachers and librarians should feel confident about estimating which online encyclopaedic websites suit the needs of a young user, in terms of their age-appropriate content and usability. Therefore, there is a need for a set of criteria for the evaluation of encyclopaedic websites for children and young adults. While evaluation of internet resources has been tackled by a significant number of researches and instructions, ${ }^{30}$ online encyclopaedic resources have been mostly overlooked in this respect so far. Jecić and Boras, for example, designed special criteria for reliability testing procedure of virtual encyclopaedias based on lexicographic characteristics. $^{31}$

\subsection{Encyclopaedias as educational websites}

Being tools for learning and education, online encyclopaedias for children and young adults represent a specific type of educational websites. Nowadays, educational websites are becoming progressively similar to electronic textbooks in terms of both content and presentation. They are becoming more advanced, bringing together rich, scholarly material and employing many of the same design elements as electronic textbooks, such as internal and external hyperlinks

\footnotetext{
${ }^{27}$ Encyclopaedia Britannica, https://www.britannica.com/place/Croatia (8.6.2017).

${ }^{28}$ Q-files The Great Illustrated Encyclopedia, https://www.q-files.com/geography/europe/croatia/ (7.6.2017)

${ }^{29}$ KidzSearch Encyclopedia, http://wiki.kidzsearch.com/wiki/Croatia (7.6.2017).

${ }^{30}$ Gi-Zen Liu; Zih-Hui Liu; Gwo-JenHwang. Developing multi-dimensional evaluation criteria for English learning websites with university students and professors. // Computers \& Education. 56 (2011) 1; pp. 65-79; Ping Zhang; Gisela M. von Dran. Satisfiers and dissatisfiers: A two-factor model for website design and evaluation. // Journal of the Association for Information Science and Technology, 51 (2000) 14; pp. 1253-1268.

${ }^{31}$ Jecić, Zdenko; Boras, Damir. Fotografija u virtualnim enciklopedijama - razrada kriterija evaluacije internetskih sadržaja. // Proceedings - 10. međunarodno savjetovanje tiskarstva, dizajna grafičkih komunikacija Blaž Baromić / Bolanča, Zdenka; Mikota, Miroslav (ur.). Zagreb, Senj: Grafički fakultet Zagreb; Matica hrvatska Senj, 2006, pp. 87-92.
} 
C. Kraus, N. Jermen, Z. Jecić, An insight into online encyclopaedias for ...

and multimedia. ${ }^{32}$ Since the internet has become an important feature of the learning environment, it is necessary to develop functional, reliable and trustworthy educational websites with appropriate content presentation, which would be adjusted to the young user's needs. According to Loranger and Nilsen, teenagers expect websites to be easy to use and to let them accomplish their tasks. They also prefer short text with words that they understand, short sentences and paragraphs. The main point of a website for teenagers is to teach them something new and keep them focused on a goal. The authors conclude that a good website for children must balance many elements like amount of text, multimedia elements, length of pages. ${ }^{33}$ Wing-Shui showed that, from the teachers' point of view, during the process of developing a high-quality educational website, web designers should put a high emphasis on ease of users' browsing experience by providing a good web navigation system. Secondly, the educational website should be appealing by appropriately manipulating multimedia elements including color, graphics, fonts and typography, which should enhance the effectiveness of achieving educational purposes of the website. ${ }^{34}$ In their study into the usability of e-encyclopaedias, Wilson et al. showed that school group users were shown to be less successful at completing tasks involving cognitive skills and at extracting relevant information from highly interactive, information abundant web sites, and there was some indication that they had a lower tolerance for unfamiliar design. ${ }^{35}$ By applying educational multimedia materials for training purposes the user should be able to understand and memorise given content. The goal is to develop efficient and high-quality multimedia content that encourages active cognitive processing and leads to the meaningful learning through creative problem solving. ${ }^{36}$

Besides setting the primary goal of a website (which determines its audience, content, function and look), every website should contain certain elements that are necessary for its successful functioning. One of the most comprehensive compilation of these elements is collected in The Research-Based Web Design

\footnotetext{
${ }^{32}$ Wilson, Ruth; Shorteed, Julie; Landoni, Monica. A Study into the Usability of E-encyclopaedias. // Proceedings of the 2004 ACM symposium on Applied computing. Nicosia, Cyprus, 2004, pp. 1688-1692.

${ }^{33}$ Loranger, Hoa; Nilsen Jakob. Teenage Usability: Designing Teen-Target Websites, Nielsen Norman Group, 4 February 2013, https://www.nngroup.com/articles/usability-of-websites-forteenagers/ (10.5.2017).

${ }^{34}$ Wing-Shui, Ng. Critical design factors of developing a high-quality educational website: Perspectives of preservice teachers. // Issues in Informing Science and Information Technology, 11 (2014), p. 105.

${ }^{35}$ Wilson, Ruth et al. (2004), ibid., p. 1691.

${ }^{36}$ Mateljan, Vladimir; Širanović, Željko; Šimović, Vladimir. Prijedlog modela za oblikovanje multimedijskih web nastavnih sadržaja prema pedagoškoj praksi u RH. // Informatologia, 42 (2009) 1, p. 39.
} 
\& Usability Guidelines (Guidelines), that was developed by the U.S. Department of Health and Human Services (HHS) in partnership with the U.S. General Services Administration and published in 2004. ${ }^{37}$ This manual, containing 209 guidelines, represents innovative, research-based approach that should result in highly responsive and easy-to-use websites for the public.

\subsection{Criteria for evaluation of usability of online encyclopaedias for children and young adults}

Based on the results of the researches explained in the previous chapter and the analysis of online encyclopaedias Britannica Kids, Q-files and KidzSearch Encyclopedia, we found the main elements that should be taken into consideration when developing a well-designed encyclopaedic website. Accordingly, we established a set of basic criteria for evaluation of usability of encyclopaedic websites intended for children and young adults.

When evaluating the usability of mentioned encyclopaedic websites, the following elements should be considered:

- Content. Apart from being reliable and adapted to the needs of end-users, in this case children and young adults, the content of an encyclopaedic website should be well-organised and presented in a way to facilitate understanding of information.

- Search engine. The search engine should be easy to use and should allow users to search the entire site and to be successful when searching. More advanced search engine options provide a drop-down list of possible results that should facilitate finding the relevant one, as children are often not sure how to construct a search query. In addition, encyclopaedic websites should provide a possibility to search the content by topics as well as alphabetically. The search engine should be present on each page, including the homepage.

- Homepage. The homepage should be simple, of limited length, and should contain all the major options available at the site along with the information about the site. Furthermore, it is important to enable access to the homepage from every page in the site.

- Links. Links are very important element in the construction of online encyclopaedic content. They enable users to access other pages with related content on the same site (internal links) or on a different site (external links). In both cases they should be active, providing a useful and reliable

\footnotetext{
${ }^{37}$ Research-Based Web Design \& Usability Guidelines, Official U.S. Government Edition. 2004. (https://www.usability.gov/sites/default/files/documents/guidelines_book.pdf). Updated version of Guidelines was published in 2006. U.S. Department of Health and Human Services (HHS) put them into a database for easier access in 2012. During 2013. HHS presented a new design of their web site and started the process of updating the Guidelines. (https://guidelines.usability.gov/).
} 
C. Kraus, N. Jermen, Z. Jecić, An insight into online encyclopaedias for ...

content. They should be well-marked, underlined and easy to notice. External links should be isolated from the main content of the site.

- Web site navigation. The website should provide users useful navigational options, such as feedback on their location and link to destination pages. It is important that users can locate where they are in the site, return to the homepage, see the query history and easily proceed to the next activity.

- Multimedia elements. In order to facilitate learning and understanding of the content, images, tables, graphs and multimedia elements should be used appropriately. They should supplement the site's content and shouldn't unnecessarily distract users. As, well they should be accompanied with accurate labelling.

- Content sharing. The site should provide a print option and sharing of the content by email or, in case of teenagers, through social networks. In addition, it is important that an encyclopaedic website provides a possibility to leave a comment to editors about the presented content.

- Online working space. Specialised websites, in this case encycloapedic websites for children and young adults, should provide to users the possibility to create their own working space which would include saving the links to the content, creating their own content and communicating with editors and other users.

\section{Evaluation of Britannica Kids, Q-files and KidzSearch Encyclopedia}

We analysed the compatibility of Britannica Kids, Q-files and KidzSearch Encyclopedia to the established criteria (Table 1).

The analysis showed that all three encyclopaedias, with their simple and shorten content, are adapted for their end users, that is kids and teenagers. In some cases the lack of definition in the articles aimed at younger population is supposed to facilitate the didactic approach, while in the case of Britannica SCHOLARS the content, as expected, is longer and more detailed. Britannica Kids and Q-files provide well-organised content, while KidzSearch provides a very elaborated information box, similar to the one in regular Wikipedia, which is not simplified and adjusted to young users' needs. All the analysed encyclopaedic websites have a simple search engine, present on each page. In addition, Britannica Kids and KidzSearch contain well-designed search engine, with Britannica Kids being the only encyclopaedia that enables alphabetical searching. As for the homepage, Britannica Kids has developed a homepage at all three levels of reading, with search engine and additional interactive content. KidzSearch homepage is simple but without any interactive content, while $Q$-files homepage contains small amount of randomly selected articles and doesn't contain the search engine. Active and well-marked links are present in all three encyclopaedias, with $Q$-files being the only one that doesn't provide any external links. 
INFuture2017: Integrating ICT in Society

KidzSearch external links did not prove to be a reliable source. Multimedia elements are well presented and elaborated in Britannica Kids and Q-files.

Table 1: Compatibility of Britannica Kids, Q-files and KidzSearch Encyclopedia to the criteria for evaluation of online encyclopaedias for children and young adults

\begin{tabular}{|c|c|c|c|}
\hline Criterion & Britannica Kids & Q-files & KidzSearch \\
\hline \multicolumn{4}{|l|}{ Content } \\
\hline Well-organised content & YES & YES & $\mathrm{NO}$ \\
\hline \multicolumn{4}{|l|}{ Search engine } \\
\hline Well-designed search engine & YES & $\mathrm{NO}$ & YES \\
\hline Enabled search by topics & YES & YES & YES \\
\hline Enabled alphabetical search & YES & $\mathrm{NO}$ & $\mathrm{NO}$ \\
\hline Search options on each page & YES & YES & YES \\
\hline \multicolumn{4}{|l|}{ Homepage } \\
\hline Simple Homepage & YES & $\mathrm{NO}$ & YES \\
\hline Enabled access to the Homepage & YES & YES & YES \\
\hline \multicolumn{4}{|l|}{ Links } \\
\hline Active links & YES & YES & YES \\
\hline Well-marked links & YES & YES & YES \\
\hline External links & YES & $\mathrm{NO}$ & YES \\
\hline Web site navigation & $\mathrm{NO}$ & $\mathrm{NO}$ & $\mathrm{NO}$ \\
\hline Multimedia elements & YES & YES & $\mathrm{NO}$ \\
\hline \multicolumn{4}{|l|}{ Content sharing } \\
\hline Enabled content sharing & $\mathrm{NO}$ & $\mathrm{NO}$ & $\mathrm{NO}$ \\
\hline Enabled print option & YES & YES & $\mathrm{NO}$ \\
\hline Online working space & $\mathrm{NO}$ & $\mathrm{NO}$ & $\mathrm{NO}$ \\
\hline
\end{tabular}

A deficiency that all three encyclopaedias showed was a poor web site navigation, which did not always allow users to find and access information effectively and efficiently. Content sharing is enabled only by print options (except for KidzSearch), and in case of Britannica Kids by e-mail, but not through social networks or by leaving comments to the editors. Furthermore, none of the analysed websites provide the option for creating a personal online working space, which could facilitate and encourage young users' learning activities.

\section{Conclusion}

Encyclopaedias have always played an important role in the process of acquiring knowledge and as such have strived to be adapted to the needs of their users. This research showed that well-established specificities regarding content organisation and presentation in traditional printed encyclopaedic works for children and young adults, which differentiate those encyclopaedias from ones targeted at adult population, exist also in the era of digital media, when the majority of encyclopaedic works are published online. Since young population tend to search for information through different online and internet services, greater attention should be given to creating of functional online encyclopaedic 
C. Kraus, N. Jermen, Z. Jecić, An insight into online encyclopaedias for ...

content intended for young users. A set of basic criteria for the evaluation of usability of online encyclopaedias for children and young adults was established, which could also serve as the basis for the development of a concept for future online encyclopaedias. Although analysed encyclopaedic websites satisfied a great deal of criteria for the successful adaptation to young users, there are still many elements that should be taken into account in the process of upgrading their usability, since all the possibilities of digital media has not yet been fully exploited. To tackle this issue there is a need for a more systemic approach to further investigations of the poorly developed field of encyclopaedistics for children and young adults.

\section{References}

Auchter, Dorothy. The evolution of the Encyclopaedia Britannica: from Macropaedia to Britannica Online. // Reference Services Review, 27 (1999) 3, pp. 291-299.

ClassConnect, http://connect.learnpad.com/content/activity.cfm?id=286650 (8.6.2017)

Flanagin Andrew J.; Metzger Miriam J. Digital Media and Youth: Unparalleled Opportunity and Unprecedented Responsibility. // MacArthur Foundation Series on Digital Media and Learning. Cambridge, MA: The MIT Press, 2008. pp. 5-28.

Gi-Zen Liu; Zih-Hui Liu; Gwo-JenHwang. Developing multi-dimensional evaluation criteria for English learning websites with university students and professors. // Computers \& Education, 56 (2011) 1, pp. 65-79.

Jecić, Zdenko. Enciklopedički koncept u mrežnom okruženju. // Studia lexicographica, 7 (2013), 2 (13), pp. 99-115.

Jecić, Zdenko; Boras, Damir. Fotografija u virtualnim enciklopedijama - razrada kriterija evaluacije internetskih sadržaja. // Proceedings - 10. međunarodno savjetovanje tiskarstva, dizajna i grafičkih komunikacija Blaž Baromić / Bolanča, Zdenka; Mikota, Miroslav (ur.). Zagreb, Senj: Grafički fakultet Zagreb; Matica hrvatska Senj, 2006, pp. 87-92.

Loranger, Hoa; Nilsen Jakob. Teenage Usability: Designing Teen-Target Websites, Nielsen Norman Group, 4 February 2013, https:/www.nngroup.com/articles/usability-of-websites-forteenagers/ (10.5.2017)

Mateljan, Vladimir; Širanović, Željko; Šimović, Vladimir. Prijedlog modela za oblikovanje multimedijskih web nastavnih sadržaja prema pedagoškoj praksi u RH. // Informatologia 42 (2009) 1, pp. 38-44.

Ping Zhang; Gisela M. von Dran. Satisfiers and dissatisfiers: A two-factor model for website design and evaluation. // Journal of the Association for Information Science and Technology, 51 (2000) 14, pp. 1253-1268.

Rain, Ella. Childrens Online Encyclopedia, http://childrens-books.lovetoknow.com/Childrens Online_Encyclopedia (26.6.2017)

Research-Based Web Design \& Usability Guidelines, Official U.S. Government Edition. 2004. https://www.usability.gov/sites/default/files/documents/guidelines_book.pdf (1.6.2017)

Strategy of education, science and technology, Official Gazette 124/2014.

Sundin, Olof; Haider, Jutta. The networked life of professional encyclopaedias: Quantification, tradition, and trustworthiness. // First Monday, 8 (2013) 6.

Wilson, Ruth; Shorteed, Julie; Landoni, Monica. A Study into the Usability of E-encyclopaedias. // Proceedings of the 2004 ACM symposium on Applied computing. Nicosia, Cyprus, 2004, pp. 1688-1692.

Wing-Shui, Ng. Critical design factors of developing a high-quality educational website: Perspectives of preservice teachers. // Issues in Informing Science and Information Technology, 11 (2014), pp. 101-113. 


\section{Links}

Encyclopedia Britannica, https://www.britannica.com/

Encyclopedia Britannica for kids - Britannica Kids, http://kids.britannica.com

KidzSearch Encyclopedia, http://wiki.kidzsearch.com/wiki/Main_Page

Q-files - The Great Illustrated Encyclopedia, https://www.q-files.com/home/

Wikipedia, http://www.wikipedia.org

World Book Online, http://www.worldbookonline.com 